\title{
De Levendes Land
}

\author{
En fortolkning
}

Af Niels Egebak

I. O, deilige Land,

Hvor Haaret ei graaner og Tid har ei Tand

Hvor Solen ei brænder og Bølgen ei slaaer

Hvor Høsten omfavner den blomstrende Vaar,

Hvor Aften og Morgen gaae altid i Dands

Med Middagens Glands!

2. Livsalige Land,

Hvor Glasset ei rinder med Graad eller Gran, Hvor Intet man savner som Ønske er værd

Hvor det ikkun fattes, som smertede her

Hvert Menneske søger med Længsel i Bryst

Din smilende Kyst!

3. Forjættede Land!

Du hilses i Morgenens speilklare Strand, Naar Barnet mon skue din Lignelse skiøn Og drømmer, du findes, hvor Skoven er grøn, Hvor Barnet kan dele med Blomster og Siv

Sit Smil og sit Liv!

4. O, flygtige Drøm

Om Evigheds-Øen i Tidernes Strøm,

Om Templet for Glæden i Taarernes Dal

Om Halvgude-Livet i Dødninge-Sal,

Med dig fra de Fleste henfarer paa Stand

De Levendes Land!

5. O, skuffende Drøm

Du skinnende Boble paa Tindernes Strøm,

Forgiæves dig Skjalden, med Mund og med Pen

Af glimrende Skygger vil skabe igien,

Naar Skyggen er ligest, da hulke de Smaa

Som stirre derpaa! 
6. Fortryllende Drøm

Om Evigheds-Perlen i Tidernes Strøm, Du giækker de Arme, der søge omsonst Hvad Hjertet begiærer, i Billed og Konst, Saa varigst de kalde hvad sikkert forgaaer Som Timer og Aar!

7. O, Kiærligheds Aand!

Lad barnlig mig kysse din straalende Haand Som rækker fra Himlen til Jorderigs Muld, Og rører vort Øie med Fingre som Guld, Saa blaalig sig hæver bag buldrende Strand Det deilige Land!

8. O himmelske Navn!

Som aabner for vores din hellige Favn, Saa Aanden, usmittet, kan røre ved Støv, Og levendegiøre det visnede Løv,

O lad mig nedknæle saa dybt i mit Leer, At Gud mig kun seer!

9. O, Vidunder-Tro!

Som slaaer over Dybet den hvælvede Bro Der Iis-Gangen trodser i buldrende Strand Fra Dødninge-Hjem til de Levendes Land, Sid lavere hos mig, du høibaarne Giæst! Det huger dig bedst!

Io. Letvingede $\mathrm{Haab!}$

Gudbroder! gienfødt i den hellige Daab! For Reiserne mange til Landet bag Hav, For Tidender gode, for Trøsten du gav, Lad saa mig dig takke, at Glæde jeg seer, Naar Haab er ei meer!

I I. O, Kiærlighed selv!

Du rolige Kilde for Kræfternes Elv

Han kalder Dig Fader, som løser vort Baand, Al Livs-Kraft i Sjælen er Gnist af din Aand Dit Rige er der hvor man Død byder Trods, Det komme til os!

I2. Vor Fader saa huld!

Du gierne vil throne i Templet af Muld, Som Aanden opbygger i Midlerens Navn, Med rygende Alter i Menneske-Favn, Med Himmellys-Bolig af Gnisten i Løn

Til Dig og din Søn! 
I3. O Christelighed!

Du skiænker vort Hjerte hvad Verden ei veed.

Hvad svagt vi kun skimte, mens Øiet er blaat,

Det lever dog i os, det føle vi godt,

Mit Land, siger Livet, er Himmel og Jord,

Hvor Kiærlighed boer!

»De Levendes Land« er et meget kommenteret digt. Det kan derfor forekomme usandsynligt, at der skulle kunne siges noget nyt om det. Under alle omstændigheder kan det ikke undgås, at endnu en fortolkning vil komme til at gentage mange alment kendte udlægninger. Dette er uvæsentligt. Væentlig er alene den eventuelle nye sammenhæng, hvori de kommer til at indgå.

Det vides at digtet er skrevet i samme versemål som Thomas Kingos »Keed af Verden, og kier ad Himlen, « og delvis som en replik til denne Kingo-tekst. Det vides også, at Grundtvig sandsynligvis selv har betragtet sin salme som et opgør med romantiken og som en indgang til den nye kristelighed, han ønskede at indstifte, og at han senere omarbejdede teksten til salmen $\mathrm{O}$ Christelighed! . Det vides endelig, at teksten er foregrebet i Grundtvigs gendigtning - med sig selv som hovedperson - af Haddingsagnet $\mathrm{i} \gg$ Nyaars-Morgen«.

Denne viden vil ikke blive fortrængt. Den vil blive sat i parenteser, som atter vil blive hævet, efterhånden som tolkningen kræver det. Men den vil udelukkende blive benyttet i en streng tekstsammenhæng, til hvis forståelse den på den anden side er nødvendig. Det bemærkes iøvrigt, at de nævnte oplysninger - i modsætning til f. eks. de biografisk-psykologiske data, tidligere fortolkere har anvendt - i sig selv er tekst-relevante, eftersom den kulturelle og litterære problematik, digtet er skrevet ind i, er at betragte som en tekst, med hvilken Grundtvigs salme har intertekstuel relation, hvorimod de biografiskpsykologiske data først bliver tekst i digtet »De Levendes Land «: de må derfor eventuelt forstås ud fra digtet, ikke digtet ud fra dem.

Ovenstående artikel er oprindelig udkommet i Torben Brostrøm m. fl.: »Fra modernisme til ny-marxistisk kritik «, hvor også amanuenserne Jørgen Bang, Flemming Harrits og Finn Stein Larsen har fortolket det samme digt og deltaget i et afsluttende symposium om selve fortolkningen og fortolkningsmetoder (Schultz' Tema-bøger, 1970). - Digtet er her optrykt efter Grundtvigs Sang-Værk III (1948) nr. 86, men med de rettelser af ordlyden, som er optaget i Den danske Lyrik 1800-1870 I s. 1 20-21, og som følger Grundtvigs håndskrift. I. linie er rettet fra $\gg$ Jeg kiender et Land $\ll$. 
En første gennemlæsning af teksten viser, at denne er bygget op i to hovedafsnit - stroferne $\mathrm{I}-6$ og stroferne 7-I 2 - med en resumerende og konkluderende finale - strofe I3 - der samtidig afdækker den skjulte dynamik bag forløbet af de foregående 12 strofer: kristentroen, som i modsætning til f. eks. Thomas Kingos kristendomsopfattelse ikke kræver, at man fornægter det dennesidige for at opnå saligheden i den hinsidige.

Ved at anbringe denne slutstrofe som indledning til den senere omdigtning vedgår Grundtvig dens strategiske betydning. At han samtidig helt forandrer et væsentligt aspekt $\mathrm{i}$ den oprindelige tekst og dermed ophæver det modsætningsforhold denne tekst er spændt op på, vil senere blive påvist.

For en nøjere betragtning viser det sig, at de to hovedafsnit består af fire mindre tekstblokke med gensidige relationer på tværs af den først iagttagne opdeling: $A$ (str. $I-3$ ) skildrer et land uden for tiden, en paradisisk tilstand, som hvert menneske siges at længes imod, og som barnet drømmer om - eller ser i lignelsen af dets egen ubekymrede tilværelse (rettere: som den voksne ser i lignelsen af barnets formodede forhold til omverdenen - sml. »Når barnet mon skue din Lignelse skøn ...«). B (str. 4-6) forkaster denne drøm - den er flygtig, bedragerisk og usand - det tabte paradis eksisterer ikke, i hvert fald ikke sådan som man almindeligt forestiller sig det, og digteren kan ikke genskabe det, for de værdier han måtte tillægge det, må han med nødvendighed hente fra sin jordiske tilværelse. Samtidig kan vore forsøg på at realisere paradisdrømmen bevirke at vi - eller i hvert fald »de Fleste《 - fornægter livet - sådan som det jo var tilfældet med Kingo, da han skrev »Keed af Verden ...«. $C$ (str. 7-9). Det tabte paradis kan imidlertid gen-tages, og gen-tages her og nu, i kraft af kristentroen, som ikke fornægter det menneskelige, men heller ikke guddommeliggør eller forguder det. Paradisdrømmen er altså alligevel ikke forgæves, den kan virkeliggøres - og på barnlig vis - ved den kærlighed, der kommer ovenned. $D$ (str. IO-12): Det er håbet, genfødt og bekræftet $\mathrm{i}$ dåben, der åbner for denne kærlighed. $\mathrm{Og}$ selvom også håbet er flygtigt som drømmen var det (»O, flygtige Drøm《 $\simeq$ »etvingede $H a a b \ll)$ så er det ikke bedragerisk som den, for det kan føre til glæden, nemlig glæden i forvisningen om, at også livet her på jorden er en del af gudsriget, som dåben har givet mennesket lod og del i: at glæden erstatter håbet, eller at håbet (drømmen) opgives til fordel for glæden, er på én gang gen-tagelsens bekræf- 
telse og betingelse. Finalen, $E$ (str. I3) peger på det, der muliggør denne gen-tagelse her og nu: Kristeligheden med dens kærlighedsbudskab, som gælder såvel på jorden som i himlen, og som bevirker, at vi kan skimte evighedslandet, ikke som i et billede, men fordi det lever i os, og vi altså allerede har del i det »mens Øjet er blaat«.

Man bemærker allerede på dette iagttagelsesniveau den ejendommelige dobbelthed, der præger teksten, og som helt skal forsvinde med omdigtningen $\gg \mathrm{O}$ Christelighed! $\ll$.

For det første er Grundtvigs opgør med Kingo koblet direkte sammen med hans opgør med romantiken. Det fælles træk er naturligvis paradisdrømmen, og i Grundtvigs dramatiske forkortning bliver denne drøm et afsatspunkt for hans egen drøm - som han ganske vist nu kalder et håb - om gennem kristendommen på jorden at virkeliggøre det paradis, som for Kingos vedkommende først kunne realiseres ved, at man sagde verden ret farvel, og for romantikerne var en fortid, som digteren kunnne genopvække i digtets lignelse, altså ligeledes ved at vende verden og virkeligheden her og nu ryggen.

Kingos bodskristendom forkastes totalt og med Kingos egne formuleringer, som blot sættes ind i nye sammenhænge og dermed negativeres. Kingos forestillingsverden i »Keed af Verden ...« parodieres i tekstens første hovedafsnit, og $\mathrm{i}$ andet hovedafsnit tages Kingo i skole: man behøver ikke at ty til Abrahams skød for træde frem for guds trone, for han troner lige så gerne »i Templet af Muld«, og i det hele taget står det vist ikke så godt til med Kingos kristentro. Hvor det f. eks. for Kingo er det verdslige, der kun er »Bobler og skrattende Kar«, er det for Grundtvig drømmen om »Halvgude-Livet i Dødningesal«, som Kingo skildrer det, der er en »skinnende Boble i Tidernes Strøm«. Og Kingos forsøg på at beskrive saligheden med så jordiske værdier som rigdom, guld, ære og yndest afvises hånligt som udslag af en forvildelse, der kalder det varigst »hvad sikkert forgaar / Som Timer og Aar«.

Men romantikens opfattelse af det barnligt naive som indgangen til det tabte paradis gentages i tekstens bøn til »Kiærligheds Aand«: »Lad barnlig mig kysse din straalende Haand / Som rækker fra Himlen til Jorderigs Muld«, hvori man hører et ekko af kristendommens bud om, at mennesket skal blive som barn igen for at komme ind $\mathrm{i}$ guds rige. Ved denne gen-tagelse hæver sig atter »Det deilige Land«, som $\mathrm{i}$ afsnit $\mathrm{B}$ blev karakteriseret som en flygtig og bedragerisk 
drøm: det er kærlighedens ånd, der kan åbne øjnene for evighedslandet, ikke den blotte drøm om det eller længslen efter det.

For det andet forkaster Grundtvig i stroferne 5 og 6 poesiens mulighed for »med Mund og med Pen« at genskabe paradisdrømmen: det bliver kun til en skygge, en lignelse, og »Naar Skyggen er ligest, da hulke de Smaa,/Som stirre derpaa!«. Ikke desto mindre har han altså selv søgt at skabe en lignelse om paradiset, nemlig digtet »De Levendes Land «! Og hvad mere er: hvis man sammenholder strofe ı's udsagn om det letvingede håb, som har muliggjort »Reiserne mange til Landet bag Hav« med den kendsgerning, at »De Levendes Land « allerede er foregrebet i Nyaars-Morgen, hvor digteren personligt tages med på et besøg til et land bag hav og siden besynger sin rejse, ligger den tolkning nær, at den glæde, der erstatter håbet, også er blevet muliggjort ved skjaldens seer-evne, digtergave og mod til at besøge »Dødninge-Hjem《, altså: konfrontere sig med dødens uafvendelighed og gennemleve tabet af drømmen om et evigt liv $i$ jordisk forstand og vende tilbage med glæden $i$ behold.

At strofen helt skifter karakter under den senere omdigtning har ingen relevans i denne forbindelse: hvis ikke det blot vidner om, at »O Christelighed « er bedre i overensstemmelse med den grundtvigianske ideologi, som først var under udformning, da »De Levendes Land « blev til! Man kan altså konstatere, at også romantikens opfattelse af digteren og hans funktion øjensynligt er blevet gen-taget i den grundtvigske kristelighed, som den kommer til udtryk i digtets førsteversion. Dette ser da også ud til at blive bekræftet ved en undersøgelse af forholdet mellem de personlige pronominer $\gg j e g \ll$ og $\gg v i \ll i$ originalteksten sammenlignet med den omdigtede tekst.

I den oprindelige tekst indtager $\gg j$ jeg en meget fremskudt position i forhold til »vi«: det er »mig«, der beder om at måtte kysse den hånd, som rækker fra himlen til jorderigs muld og rører »vort« øje; det er mig « der gerne vil nedknæle så dybt $\mathrm{i} \gg m i t \ll$ ler, at gud »mig« kun ser; og det er »mig«, den højbårne gæst skal sidde hos, ligesom det er »mig «, der takker for rejserne til landet bag hav og for de tidender og den trøst »jeg《 har fået - og kan bringe videre til menneskeheden. Og der kan næppe herske tvivl om, at denne »jeg « er skjalden selv, seeren der ved, at »Dit Rige er dér, hvor man Død byder Trods«. Derfor må den »Livs-Kraft i Sjælen«, som strofe I I taler om, og som siges at være »Gnist af din Aand «, også betragtes som guds særlige gave til den kristne digter, som gennem sin salmedigtning videre- 
giver sine erfaringer. I $\gg \mathrm{O}$ Christelighed! $\ll$ er dette modsæetningsforhold fjernet: den oprindelige strofe 8 er strøget, og de fire øvrige strofer omskrevet som følger, så at »jeg《overalt er erstattet af »vi« (»os《):

O Vidunder-Tro!

Du slaar over Dybet din gyngende Bro

Som Isgangen trodser i brusende Strand

Fra Dødninge-Hjem til de Levendes Land;

Bo lavere hos os, det huger dig bedst,

Du højbaarne Gjæst!

Letvingede Haab!

Gudbroder, nyfødt i den hellige Daab!

O laan os den Fjederham, Aanden dig gav,

Saa tit vi kan flyve til Landet bag Hav,

Hvor Evigheds Sol skinner klart allen Stund

Paa Saligheds Grund!

O, Kjærlighed selv!

Du rolige Kilde for Kræfternes Elv!

Du fylder med Frelserens gavmilde Ord

Velsignelsens Kalk paa det kristne Gudsbord;

O vær du vor Livdrik paa Jorden og bliv

Vort evige Liv!

O, Kjærligheds Aand!

Det evige Liv i Fuldkommenheds Baand!

$\mathrm{O}$, smelt du vort Hjærte ved Højaltrets Ild,

Og klar du Jordklimpen i Solglansen mild,

Saa glade vi føle, os skabes i Bryst

De Levendes Lyst!

Iagttager man nu de fire tekstblokkes »sammenkobling«, vil man straks opdage, at afsnit $\mathrm{G}$ adskiller sig fra de øvrige derved, at tekstforløbet er det omvendte af det logiske forløb. Afsnittet skildrer den flere gange omtalte gen-tagelse af det tabte paradis. Men det, der gør gen-tagelsen mulig, nævnes først i afsnittets sidste strofe (strofe 9): det er troen, der bygger bro mellem det dennesidige (»de Levendes Land «) og det hinsidige (»Dødninge-Hjem《), den bevirker, at dødningehjemmet fra at være scenen for »Halvgude-Livet « (strofe 4) bliver til »Det deilige Land«, og det er i kraft af den, digteren kan udbryde: »Sid lavere hos mig du høibaarne Giæst!/ Det huger dig bedst!《 
Denne spejlvending af afsnit $\mathrm{C}$ i forhold til de øvrige afsnit bevirker, at hele andet hovedafsnit også kan læses som en spejlvending af første hovedafsnit, og den forekommer at være af betydning for tekstens udsagn om forholdet mellem romantik og kristendom.

Ved kombination af de fire tekstafsnit indbyrdes kan man påvise deres gensidige relationer på tværs af de to store hovedafsnit, de iøvrigt indgår i. Af de 6 mulige kombinationer vil af pladshensyn kun de tre væsentligste blive omtalt, nemlig $A+C, B+C$ og $A+D$, som alle tre illustrerer den omtalte spejlvending.

$$
I: A+C
$$

I. Drømmen om det dejlige land vs

2. Længslen efter det livsalige land

3. Barnet formodes at skue landet vs i en lignelse
9. Drømmens opfyldelse ved troen

8. Opfyldelsen ved ånden

7. Landet ses i kraft af kærligheds ånd

$$
\text { II: } B+C
$$

4. Drømmen om halvgudelivet i vs dødningesal

5. Den skuffende drøm, poesiens vs afmagt

6. Den bedrageriske drøm, kun- vs stens forfængelighed
9. Troen på Guds tilstedeværelse på jorden

8. Andens levendegørende virksomhed

7. Kærlighedens skabermagt

$$
\text { III: } A+D
$$

3. Barnet skuer lignelsen af landet vs io. Den kristne digters vished om landets eksistens

2. Menneskets længsel efter landet vs II. Landet findes her og nu i kraft af kærligheden og Guds ånd

I. Drømmen om det dejlige land vs I2. Kristendommens virkeliggørelse af landet her på jorden

De opstillede skemaer over de enkelte strofers indbyrdes »sammenkobling « viser da, at der i teksten er tale om fuldstændig gen-tagelse, $\mathrm{i}$ kristentroen og af den kristne digter, af den romantiske digters drøm om det dejlige land: den tabte uskyld er ikke tabt, den kan genvindes ved dåben, poesien er ikke magtesløs, den får magt ved gnisten af guds ånd, lignelsen, som i den ikke-kristne digtning og kunst kun var en skuffende og bedragerisk drøm, bliver i den kristne salmedigtning 
til et håb som bringer glæde, hvor drømmen kun bragte sorg og nød. En sammenstilling af de to centrale strofer - str. 4 og str. I0, som indleder de to parallelt løbende afsnit B og D - kan yderligere godtgøre dette: strofe 4 begynder svaret på romantikens opfattelse af det dejlige land, strofe io kommenterer kristendommens vision af landet, og man bemærker, at der bortset fra konklusionen: død vs glæde, er fuldstændig parallelitet mellem de to strofers udsagn.

\begin{tabular}{|c|c|c|}
\hline »flygtige drøm《 & $\simeq$ & »letvingede håb« \\
\hline »evigheds-øen i tidernes strøm《 & $\simeq$ & ». . genfødt i den hellige dåb \\
\hline »templet for glæden« & $\simeq$ & $\gg$ landet bag hav« \\
\hline »halvgudelivet« & $\simeq$ & »trøsten du gav« \\
\hline$» \mathrm{~d} ø \mathrm{~d} \ll$ & vs & »glæde« \\
\hline
\end{tabular}

Forskellen mellem de to versioner af det dejlige land opstår med andre ord som de forskellige resultater af henholdsvis »drøm《 og »håb«: den flygtige drøm lader sig ikke fastholde, det ikke mindre flygtige håb formidles gennem dåben og kristeligheden (»...Templet af Muld / Som Aanden opbygger i Midlerens Navn ... «); derfor er håbets letvingethed « ikke udelukkende en negativ egenskab som drømmens »flygtighed «, for den sætter den kristne salmist i stand til at udføre, hvad den romantiske digter ikke magtede: at kende det land, som de begge drømmer om, og bringe menneskene pålidelige tidender om det, først og fremmest fordi han har indset, at det må søges her og ikke hverken $i$ en fjern fortid eller $i$ et kommende lykkerige.

Denne forskel mellem drømmens og håbets resultater har nøje forbindelse med deres holdning til visionen af det dejlige land: en nærmere betragtning af de to versioner afslører nemlig, at den romantiske drøm udelukkende karakteriserer landet ved negative egenskaber, mens det kristne håb skildrer det ved positive egenskaber:

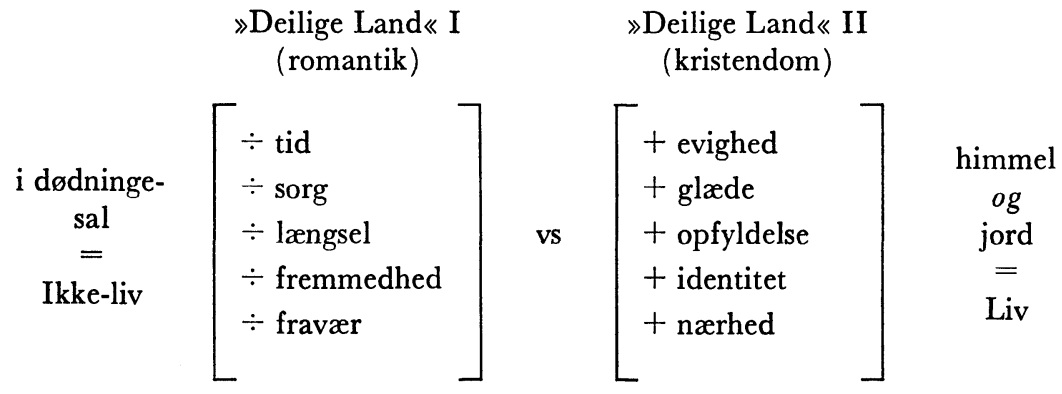


Den romantiske drøm må derfor i følge tekstsammenhængen nødvendigvis føre til »Død«, mens det kristne håb i kraft af troen og kærligheden, formidlet af dåben, selv når det ikke er mere, må karakteriseres som »Ikke-død «.

Analysen af teksten og konstruktionen af dens paradigme har således vist, at det egentlige modsætningsforhold, den er spændt op på, er modsætningen mellem »liv« og »død《. Eller rettere: på to forskellige visioner af forholdet »liv« vs »død《, og på det ene fænomens dominans over det andet. Hvis man lader stort bogstav betyde dominans og lille bogstav ikke-dominans kan de to visioner - som Grundtvig forestillede sig dem - opstilles $\mathrm{i}$ de to følgende ligninger, hvor » $\mathrm{E}_{\ll}$ betyder: »eksistens《

$$
\begin{aligned}
\text { I: } & \mathrm{E}_{1}=\mathrm{liv}+\text { Død } \\
\text { II: } & \mathrm{E}_{2}=\mathrm{Liv}+\mathrm{død}
\end{aligned}
$$

I er romantikens (subs. Kingos) forhold til syndromet liv/død II er kristenlivets (in casu Grundtvigs) forhold til samme syndrom

Som følge af den forskellige dominans får drømmen/håbet forskellige funktioner i de to afsnit. Det samme gør digteren. Derfor er det den kristne salmist - »jeg « - der kan formidle gen-tagelsen af den romantiske drøm til menneskene og dermed kristendommens glade budskab. Derfor er han også så centralt placeret i tekstens original-version.

Der er altså på én gang tale om et modsætningsforhold og en gensidig implikation mellem kristendom og romantik i den foreliggende tekst, et modsætningsforhold og en gensidig implikation, der har direkte relation til forholdet mellem drøm og håb eller mellem død og ikke-død. Forholdet kan opstilles i følgende skema (som svarer til den semantiske grundmodel for signifikationens elementære struktur):

G

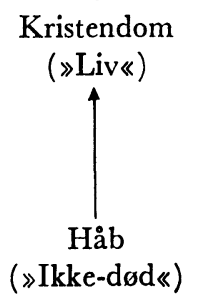

D
A

Romantik

(»Ikke-liv«)

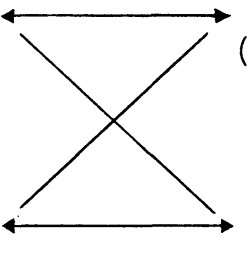

(»Død «)

B 
Som skemaet viser, er det formodede opgør med romantiken endnu ikke fuldbyrdet med denne tekst. Man iagttager tværtimod et spændingsforhold mellem romantik og kristendom, en endnu uafgjort kamp mellem to livsopfattelser, eller mellem en etableret ideologi (romantiken) og en ideologi i færd med at finde sin bane (grundtvigianismen).

Sammenligner man original-versionen, som her er blevet analyseret, med den langt senere omarbejdelse »O Christelighed!«, må man konstatere, at i den sidste er slaget endelig vundet, spændingsforholdet og dobbeltheden forsvundet. Og det til den grad, at en strofe, som i original-versionen er placeret i negativ belysning, nemlig i forbindelse med den romantiske drøm om »det livsalige land « - den drøm, som umiddelbart efter karakteriseres som flygtig, skuffende og bedragerisk - tværtimod i »O Christelighed!« står utvetydigt positivt, skønt den på trods af en vis omdigtning udtrykker nøjagtigt den samme forestillingsverden $(\div$ tid, $\div$ sorg, $\div$ længsel $)$ :

\section{DE LEVENDES LAND}

Livsalige Land

Hvor Glasset ei rinder med Graad eller Gran

Hvor Intet man savner, som Ønske er værd

Hvor det ikkun fattes, som smertede her

Hvert Menneske søger med Længsel

Din smilende Kyst!
O CHRISTELIGHED!

Livsalige Land

Hvor Glasset ej rinder med Graad eller Sand

Hvor Blomsten ej visner, hvor

Fuglen ej dør

Hvor Lykken er skinnende klar

men ej skør

Hvor dyrt ikke kjøbes til Krone

på Baar

De snehvide Haar!

Den grundtvigianske ideologi er etableret. Men det gjorde ikke Grundtvig til en større digter, at han nu versificerede fastslåede sandheder $\mathbf{i}$ stedet for, gennem sin poesi og i kraft af den, at søge mod ny erkendelse. 